\title{
Rhizobacteria cooperative effect against Meloidogyne javanica in rhizosphere of legume seedlings
}

\author{
F.-S. Tabatabaei ${ }^{1}$ and A. Saeedizadeh ${ }^{2 *}$
}

Summary Root-knot nematodes are major pests of legume fields in Iran. This research evaluated the effect of Rhizobium leguminosarum bv. phaseoli and Pseudomonas fluorescens CHAO (stand alone and combination treatment) on galling and reproduction of root-knot nematode, Meloidogyne javanica, in legum (chickpea, bean, lentil, pea) seedling rhizosphere, and the growth properties of the host plants. The legumes seeds were sown in $1 \mathrm{~kg}$ sterilized sandy loam soil. Inocula were $5 \mathrm{~J} / \mathrm{g}$ of soil, in the case of the nematode, while considering the bacteria $1 \times 10^{7} \mathrm{cfu} / \mathrm{kg}$ soil. A treatment of nematicide (cadusafos) was performed, as a commonly used nematicide in Iran, at $2 \mathrm{~g} / \mathrm{kg}$ soil. Two months after inoculation, the following parameters were recorded: the number of knots, egg masses and reproduction factor of the nematode, bacterial nodules per root, and growth properties of seedlings in the treatments (control, nematode, nematode+nematicide, and nematode+rhizobacteria). The greatest bacterial effect on the control of the nematode was observed in the rhizosphere of the bean treatments. Inoculation with Rhizobium in the soil decreased the galling on the legumes' roots, and the combined inoculation with Pseudomonas and Rhizobium resulted in a higher decrease of the galling.

Additional keywords: antagonism, biocontrol, management, nodule, Pseudomonas, root-knot nematode

\section{Introduction}

Legumes are well recognized for their seeds, which are rich of proteins, minerals and vitamins (Bojnanska et al., 2012), and their significant role in maintaining productivity in agricultural systems (Dashadi et al., 2011). After cereals, leguminous crops are the most important crops in Iran (Alizadeh et al., 2013).

Root-knot nematodes (Meloidogyne spp.) are known as a major constraint to leguminous plants, causing yield losses in heavily infested fields (Onyeke and Akueshi, 2012). They are very important plant parasitic nematodes due to their worldwide distribution, wide host range, many species and interactions with root rot and wilt fungi and bacteria (Nicol, 2002; Perry and Moens, 2006). Meloidogyne javanica (Treub) Chitwood has a broad host range and great dispersal, making plant roots more vulnerable to root rot pathogens

\footnotetext{
1 Senior Expert, Center of Agricultural Research, Pishva, Varamin, Tehran, Iran

2 Assistant Professor, Department of Plant Protection, Faculty of Agricultura, Shahed University, Tehran, Iran

* Corresponding author: ayatsaeed314@gmail.com
}

in Iran (Hosseini Nejad and Khan, 2001).

A number of biocontrol agents have demonstrated high potency in reducing damage by nematodes in different crops (Gupta et al., 2015). Natural enemies of nematodes are successful in reducing the activity of plant parasitic nematodes through parasitism, secretions (toxin, antibiotic and enzyme), competition, inducing systemic resistance and stimulation of host resistance (Tian et al., 2007). There are many examples of research in the field of biological control of plant parasitic nematodes, especially root-knot nematodes, due to the application of various microorganisms, including bacteria (Ashoub and Amara, 2010; Jang et al., 2016; Ntalli and Caboni, 2012; Saeedizadeh, 2016; Sokhandani et al., 2016).

In a rhizosphere, significant and intensive interactions take place between the plant, soil and microorganisms (Panizzon et al., 2016). Plant growth-promoting rhizobacteria (PGPR) are free-living bacteria that may impart beneficial effects on plants (Nihorimbere et al., 2011). PGPR enhance emergence, colonize roots and stimulate overall plant development. The presence of rhizobia in a 
rhizosphere may protect the host root from damage induced by pathogens (Lipiec and Glinski, 2011). Therefore, the handling of rhizosphere by inoculation of PGPR has shown considerable promise for biocontrol of plant pathogens (Ahemad and Kibret, 2014).

Rhizobacteria-nematodes interactions have been extensively considered to manage plant-parasitic nematodes (Shaikh et al., 2016; Siddiqui and Akhtar, 2009). Rhizobacteria genera such as Pasteuria, Pseudomonas and Bacillus have a respectable potential as biological control agents against plant parasitic nematodes (Beneduzi et al., 2012). Most frequently studied antagonistic rhizobacteria to affect the nematodes are Bacillus subtilis, Bacillus sphaericus and Pseudomonas fluorescens (Ashoub and Amara, 2010; Muthulakshmi et al., 2010). On the other hand, infestation by nematodes is known to suppress bacterial nodulation and consequently decrease nitrogen fixation in leguminous plants (Siddiqui et al., 2013).

Rhizobium forms an endosymbiotic nitrogen-fixing association with roots of legumes and it can also act as a biocontrol agent on root-knot nematodes exhibiting the capacity to colonize plant roots and the nematode galls (Siddiqui and Akhtar, 2009). $P$. fluorescens $\mathrm{CHAO}$ has been introduced as biocontrol agent of root-knot nematodes. The bacterium has been able to suppress the nematodes populations through the production of secondary metabolites (Siddiqui et al., 2006).

Taking into account the importance of root-knot nematodes and the need for biological control methods, the scope of the research was to evaluate the effect of $R$. leguminosarum bv. phaseoli and $P$. fluorescens $\mathrm{CHAO}$ as rhizobacteria against $M$. javanica in legumes seedling rhizosphere, and growth properties of the plants.

\section{Materials and Methods}

\section{Preparation of nematode inoculum}

Infested roots with root-knot nematodes were sampled from a population maintained in the fields of tomato plants (cv. Walter) in the southern Tehran city, Iran. Extraction and preparation of $M$. javanica inoculum were applied according to the Hussey and Barker (1973) using the single egg mass method. According to the morphological and morphometrical characteristics of body and perineal pattern, the nematodes were initially identified (Aydinli and Mennan, 2016). The egg mass of the species was added to the rhizosphere of tomato seedling cv. Local; the nematode was multiplied and second stage juveniles $\left(\mathrm{J}_{2}\right)$ were finally obtained in a glasshouse ( 10 hours lighting and $25 \pm 2^{\circ} \mathrm{C}$ temperature). Infected tomato roots bearing large egg masses were incubated in water for three days at $28 \pm 2^{\circ} \mathrm{C}$ and hatched $\mathrm{J}_{2}$ were collected and counted. The nematode inoculum level of the treatments was determined as $5 \mathrm{~J}_{2} / \mathrm{g}$ of soil (Gharabadiyan et al., 2013).

\section{Preparation of bacterial inoculum}

$P$. fluorescens $\mathrm{CHAO}$ and $R$. leguminosarum bv. phaseoli were obtained from the culture collection of the Department of Plant Pathology, Shahed University, Tehran, Iran.

\section{P. fluorescens $\mathrm{CHAO}$}

The bacterium was prepared as a bacterial inoculum suspension according to Weller and Cook (1983). A full loop of 48-hour culture of the bacterium on King's medium $B$ (King B) was transferred to a flask containing $100 \mathrm{ml}$ King $B$ liquid medium and incubated for 48 hours on a shaker (120 RPM) at $27^{\circ} \mathrm{C}$. Bacterial suspension was centrifuged for 10 min @ 6000g, and washed for 2-3 times with a natural salt solution $(\mathrm{NaCl} 0.14 \mathrm{M})$ to remove residual nutrient medium. Bacterial cells were extracted by recentrifuging and suspending to a solution of $1 \times 107 \mathrm{cfu} / \mathrm{ml}$, which was prepared using the standard curve spectrophotometrically in a carboxymethyl cellulose solution. To develop the optimal amount of inoculants, this solution was diluted by Tween80 (0.02\%) (Weller and Cook, 1983).

\section{R. leguminosarum bv. phaseoli}

To activate the bacterium, $1 \mathrm{ml}$ of liquid 
medium of YMA (Yeast Mannitol Agar) under sterile conditions was added to bacteria. For bacterial proliferation, one inoculation loop of the bacterium dissolved in $100 \mathrm{ml}$ of liquid YMA and incubated on an orbital shaker @ 200 RPM for 24 h. For concentration determination of the bacterial suspension, the Rhizobium was cultured in a liquid medium of YMA and incubated on an orbital shaker @ 200 RPM for $24 \mathrm{~h}$ at $25^{\circ} \mathrm{C}$ (Sadovinkova et al., 2003). The culture was centrifuged @1000g for 10 min and was resuspended with phosphate buffer. If the optical density (OD620) of this solution was 0.1 , it means $108 \mathrm{cfu} / \mathrm{ml}$. To develop the optimal amount of inoculants (107cfu/ml), this solution was diluted by phosphate buffer (Bai et al., 2003).

\section{Plant material and inoculation}

The seeds of four legumes, including chickpea (Cicer arietinum L., Cv. Sefid), bean (Phaseolus vulgaris L., Cv. Bahman), lentil (Lens culinaris Medikus, cv. Gachsaran), and pea (Pisum sativum L., cv. Shamshiri) were obtained from Department of Plant Protection, Shahed University, Tehran, Iran. They were surface-sterilized by $70 \%$ ethanol for $2 \mathrm{~min}$ and $1 \%$ sodium hypochlorite for 5 min, and rinsed 5 times with distilled water (Wang and Oyaizu, 2009). Four seeds were sown in $1 \mathrm{~kg}$ steam-sterilized sandy loam soil in the greenhouse; and one week after germination thinning was done to save a single seedling per pot. The plants were inoculated at the trifoliate emergence stage. The seedlings were kept in a greenhouse (natural light and $25 \pm 2^{\circ} \mathrm{C}$ ).

The nematode inoculum was set at $5 \mathrm{~J} / \mathrm{g}$ soil, the bacteria at $1 \times 10^{7} \mathrm{cfu} / \mathrm{kg}$ soil, and the nematicide RUGBY $10 \mathrm{G}$ (Cadusafos), as a reference product, at $2 \mathrm{~g} / \mathrm{kg}$ soil (Safdar et al., 2012). The inocula were individually applied to the pots in a volume of $5 \mathrm{ml}$ suspension in a ring from around the plant root to a depth of $3 \mathrm{~cm}$. Control comprised of healthy untreated seedlings (free of the nematode and bacteria inocula). Each pot plant represented one replication.

\section{Measurement of growth properties of the plants}

Plants were uprooted 60 days after inoculation and the root systems were gently washed. The plants were cut with a knife above the base of the root emergence zone. Excess water was removed by blotting before weighing shoots and roots separately.

\section{Evaluation of $M$. javanica activity in the plants}

According to the proposed method of Hussey and Janssen (2002), activity of $M$. javanica was evaluated in the control and treated plants as the number of egg masses and knots per root, and final population and reproduction factor per pot. At first, the roots of the plants were washed with tap water and drained on blotting paper. To specify the number of egg masses, roots were divided into $3-4 \mathrm{~cm}$ parts and egg masses were stained with Floxin solution B $(0.15 \mathrm{~g} / \mathrm{l}$ of water), bleached with lactophenol and counted under a dissecting microscope (Hussey and Janssen, 2002). For determination of the nematode population in the pot soil, a $250 \mathrm{~g}$ subsample of well mixed soil was processed according to Jenkins (1964), known as centrifuge or sugar flotation method. The number of nematodes in prepared suspension was used to calculate the population of nematodes per pot ( $1 \mathrm{~kg}$ soil). To count the number of juveniles, eggs and females inside the root, $1 \mathrm{~g}$ sub-sample of the root was macerated in a Waring blender and counts were done on the suspension thus obtained. The numbers of nematodes present in the root were calculated by multiplying the numbers of nematodes present in $1 \mathrm{~g}$ of the root with the total weight of the root. The reproduction factor was calculated utilizing the equation $\mathrm{RF}=\mathrm{Pf} / \mathrm{Pi}$, which is $\mathrm{RF}$ : reproduction factor, Pf: final population of the nematode, and Pi: primary population of the nematode (Osei et al., 2010).

\section{Statistical analysis}

This experiment was based on a Complete Randomized design with four legumes species and 12 treatments for the 
management of $M$. javanica, including: control (with no the inoculum of the nematode and the bacteria), rhizobium (R), pseudomonas $(\mathrm{P})$, nematode $(\mathrm{N})$, rhizobium + pseudomonas (RP), rhizobium + nematode (RN), pseudomonas + nematode (PN), rhizobium + pseudomonas + nematode (RPN), rhizobium + nematode (a week later) $(\mathrm{Rn})$, pseudomonas + nematode (a week later) $(\mathrm{Pn})$, rhizobium + pseudomonas + nematode (a week later) (RPn), and nematode + nematicide (NN). The treatments were replicated four times. The data were subjected to one way analysis of variance (ANOVA). Mean treatments were compared using a Duncan multiple range test. All analyses were performed by using SAS software version 9.1.

\section{Results}

The experiment revealed significant differences between the various treatment and crop combinations (ANOVA, $p \leq 0.05$ ). The greatest bacterial effect on the control of the nematode was observed in bean treatments (Table 1). The plant roots in the Pseudomonas treatment produced less galls than those in the nematode treatment (Table 1) However, higher galling occurred on the roots treated with Rhizobium. Combined application of Rhizobium and Pseudomonas caused a lower reduction in galling and multiplication of the nematode than the nematicide (Table 1).

The level of the nematode activity (gall, egg mass and reproduction factor) was higher on the treatments of lentil plants followed by bean, pea and chickpea (Table 1). The lowest nematode activity was noted in the nematicide treatment (Table 1). Inoculation of Pseudomonas and Rhizobium reduced nematode activity, especially in the treatments Pn, Rn and RPn, where the inoculation with the nematode was conducted one week after the bacteria inoculation (Table 1). The treatments of Pseudomonas have been more effective than Rhizobium on reducing the nematode activity (Table 1).

The bacterial nodulation of Rhizobium on the legume roots infested by the nematode was lower than on those at the Rhizobium treatment $(\mathrm{R})$ (Table 2). Also the infested roots by the nematode, in the treatments which received the co-inoculation of Pseudomonas and Rhizobium, produced fewer nodules than those in the stand alone treatment of Rhizobium (Table 2). The descending order of the number of bacterial nodules obtained was: chickpea>pea>bean>lentil (Table 2). The nematode was more effective in reducing bacterial nodulation by Rhizobium in comparison with Pseudomonas. The number of bacterial nodules obtained in the treatments was in descending order: $\mathrm{R}>\mathrm{RP}>\mathrm{RPn}>\mathrm{Rn}>\mathrm{RPN}>\mathrm{RN}$ (Table 2).

Data analysis of plant growth properties indicated a difference between the fresh weight of root and shoot in all treatments, compared with the control (Figures 1 and 2); this difference was positive in all treatments, except the treatment with the nematode $(\mathrm{N})$. The greatest increase (positive difference) of root and shoot fresh weight were obtained in the treatments with the bacteria (Pseudomonas and Rhizobium) inoculation, either with or without the nematode (Meloidogyne) inoculations (P, R, RP) (Figures 1, 2). The highest increase in fresh weight of root and shoot was observed in the treatments $R P, R$ and $P$ (descending order). The inoculation with the nematode resulted in the least weight of roots and shoots. The highest reduction in root and shoot weight was obtained in the nematode treatment of lentil and bean (Figures 1 and 2).

\section{Discussion}

Our results indicate that inoculation with Rhizobium and Pseudomonas in stand-alone application can reduce Meloidogyne activity in the rhizosphere of the legumes seedlings. Rhizobium decreases the nematode galling while the nematode reduces the bacterial nodules on the roots of the plants and consequently decreases nitrogen fixation in leguminous plants (Siddiqui et al., 2013). Other studies have also indicated an increased 


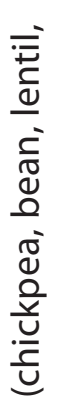

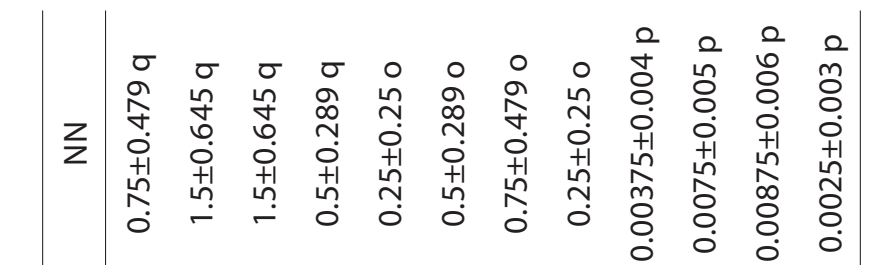

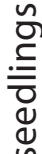

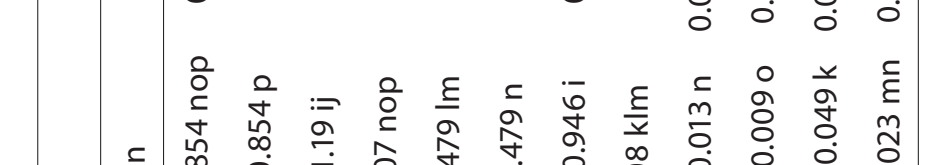

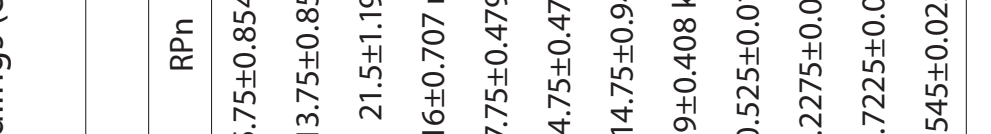

$\stackrel{\text { है }}{\frac{1}{5}}$

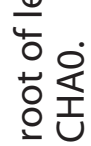

○ิ 气ิ

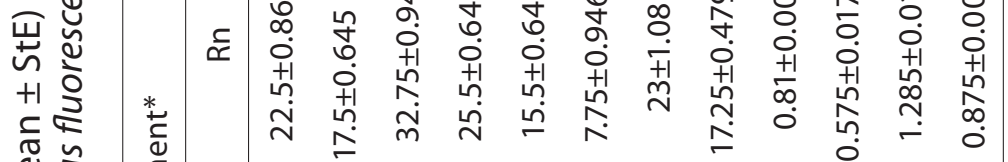

ฮె

हु

言

政

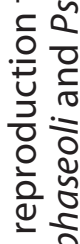

突

है

陼

ब.

产:

要

व.

产

(2)

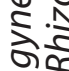

용

竞

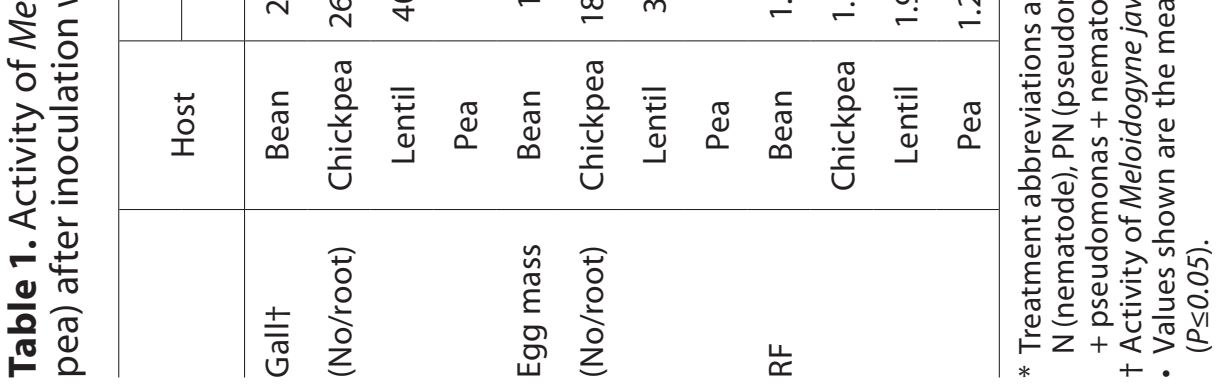

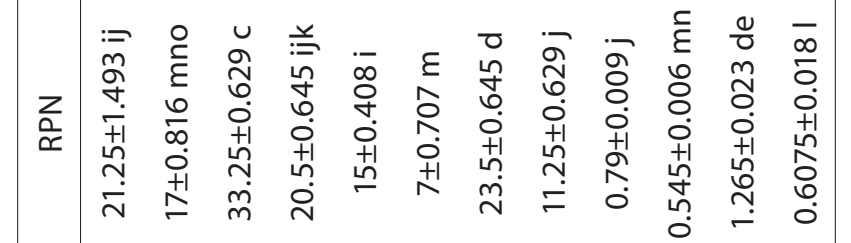

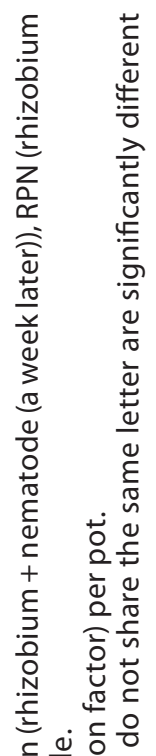

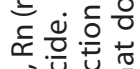

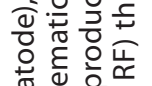

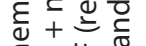

$\div \frac{1}{\circ}$

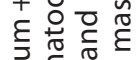

응 峲宁

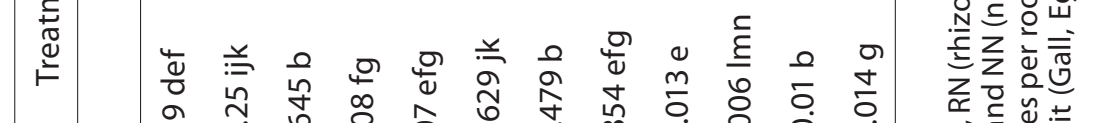

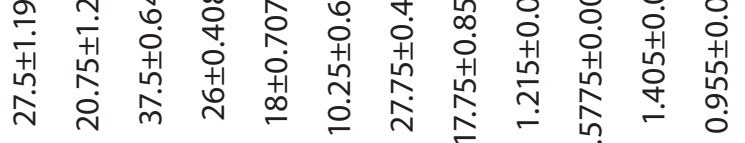

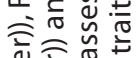

to

离

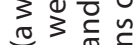

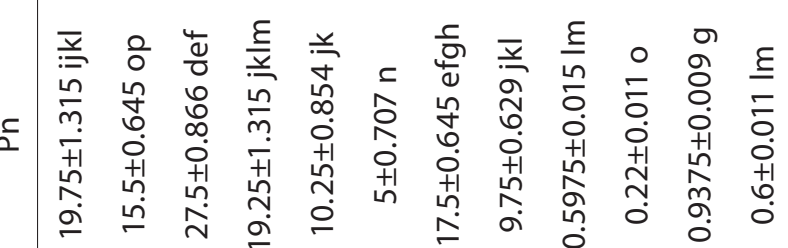

造 $\frac{\pi}{0} \frac{\pi}{0} \sum^{\frac{\pi}{0}}$

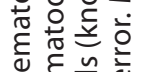

我

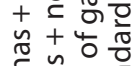

ᄃ

응

ब⿳⺈⿴囗十大

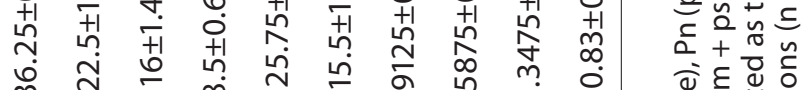

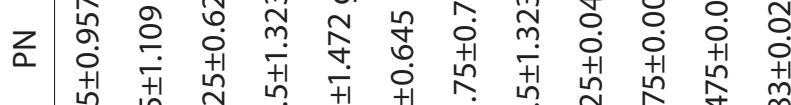

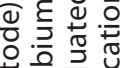

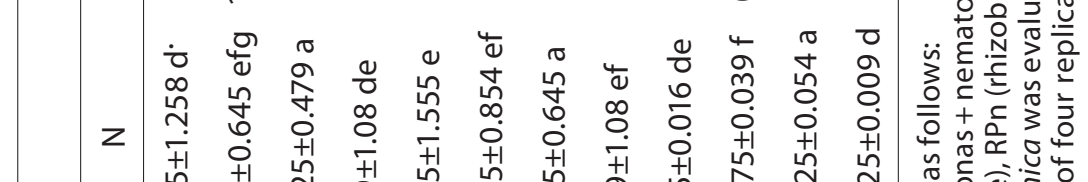

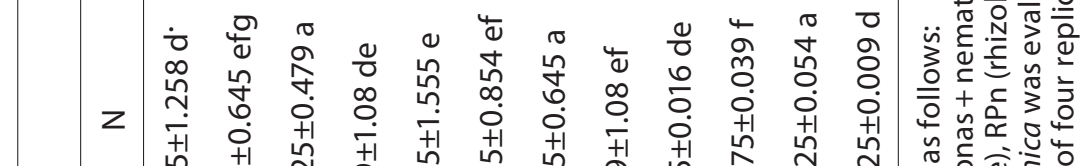

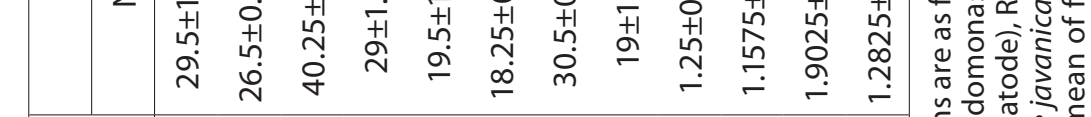

(c) Benaki Phytopathological Institute 
Table 2. Number of bacterial nodules of Rhizobium leguminosarum bv. phaseoli (Mean $\pm \mathrm{StE}$ ) on root of legume seedlings.

\begin{tabular}{l|cccccc}
\hline \multirow{2}{*}{ Plant $\dagger$} & \multicolumn{5}{|c}{ Treatment* } \\
\cline { 2 - 7 } & $\mathrm{R}$ & $\mathrm{RN}$ & $\mathrm{Rn}$ & $\mathrm{RP}$ & $\mathrm{RPN}$ & $\mathrm{RPn}$ \\
\hline Bean & $17 \pm 0.41 \mathrm{abc}$ & $9.25 \pm 0.63 \mathrm{k}$ & $13 \pm 0.91 \mathrm{fghi}$ & $14 \pm 0.41 \mathrm{defg}$ & $12.25 \pm 0.85 \mathrm{ghi}$ & $14.25 \pm 0.85 \mathrm{defg}$ \\
Chickpea & $19 \pm 0.91 \mathrm{a}$ & $11.75 \pm 0.85 \mathrm{hij}$ & $17.5 \pm 0.65 \mathrm{ab}$ & $17.5 \pm 0.87 \mathrm{ab}$ & $15.5 \pm 0.65 \mathrm{bcd}$ & $17 \pm 1.08 \mathrm{abc}$ \\
Lentil & $15 \pm 0.41 \mathrm{cdef}$ & $6.5 \pm 0.65 \mathrm{I}$ & $11 \pm 0.71 \mathrm{ijk}$ & $12.25 \pm 0.85 \mathrm{ghi}$ & $11.75 \pm 0.85 \mathrm{hij}$ & $12.25 \pm 0.85 \mathrm{ghi}$ \\
Pea & $17.5 \pm 0.65 \mathrm{ab}$ & $10 \pm 0.41 \mathrm{jk}$ & $12.75 \pm 1.11 \mathrm{ghi}$ & $15.5 \pm 0.65 \mathrm{bcde}$ & $13.75 \pm 0.63 \mathrm{efgh}$ & $16 \pm 0.41 \mathrm{bcd}$ \\
\hline
\end{tabular}

* Treatment abbreviations are as follows:

$\mathrm{R}$ (rhizobium), RN (rhizobium + nematode), Rn (rhizobium + nematode (a week later)), RP (rhizobium + pseudomonas), RPN (rhizobium + pseudomonas + nematode) and RPn (rhizobium + pseudomonas + nematode (a week later)).

† Activity of Rhizobium leguminosarum bv. phaseoli was evaluated as the number of nodules per root.

- Values shown are the mean of four replications $(n=4) \pm$ standard error. Means that do not share the same letter are significantly different $(p \leq 0.05)$.

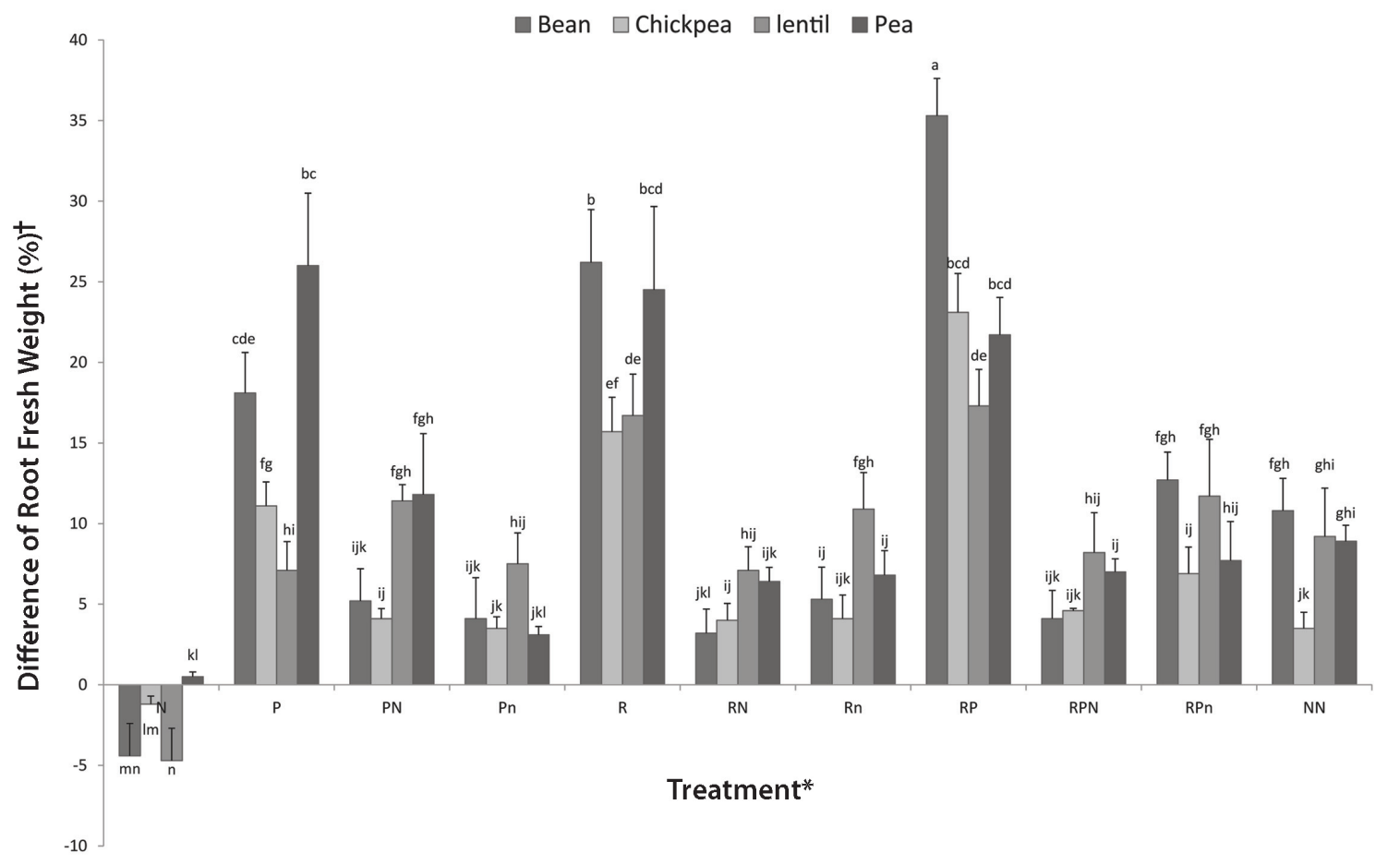

Figure 1. Effect of inoculation with Rhizobium leguminosarum bv. phaseoli and Pseudomonas fluorescens CHAO on root fresh weight of legume seedlings infested with root-knot nematode Meloidogyne javanica, as compared with control* † Each value has been calculated using the equation: $\frac{\text { Treatment mean-control mean }}{\text { control mean }} \times 100$

* Completely randomized design with four replications. Treatment abbreviations are as follows:

$\mathrm{N}$ (nematode), P (pseudomonas), PN (pseudomonas + nematode), Pn (pseudomonas + nematode (a week later)), R (rhizobium), RN (rhizobium + nematode), Rn (rhizobium + nematode (a week later)), RP (rhizobium + pseudomonas), RPN (rhizobium + pseudomonas + nematode), RPn (rhizobium + pseudomonas + nematode (a week later)) and NN (nematode + nematicide).

- Control comprised of healthy untreated seedlings (free of the nematode and bacteria inocula).

Comparisons were carried out using Duncan test $(a=0.05)$; means that do not share the same letter are significantly different $(p \leq 0.05)$. 


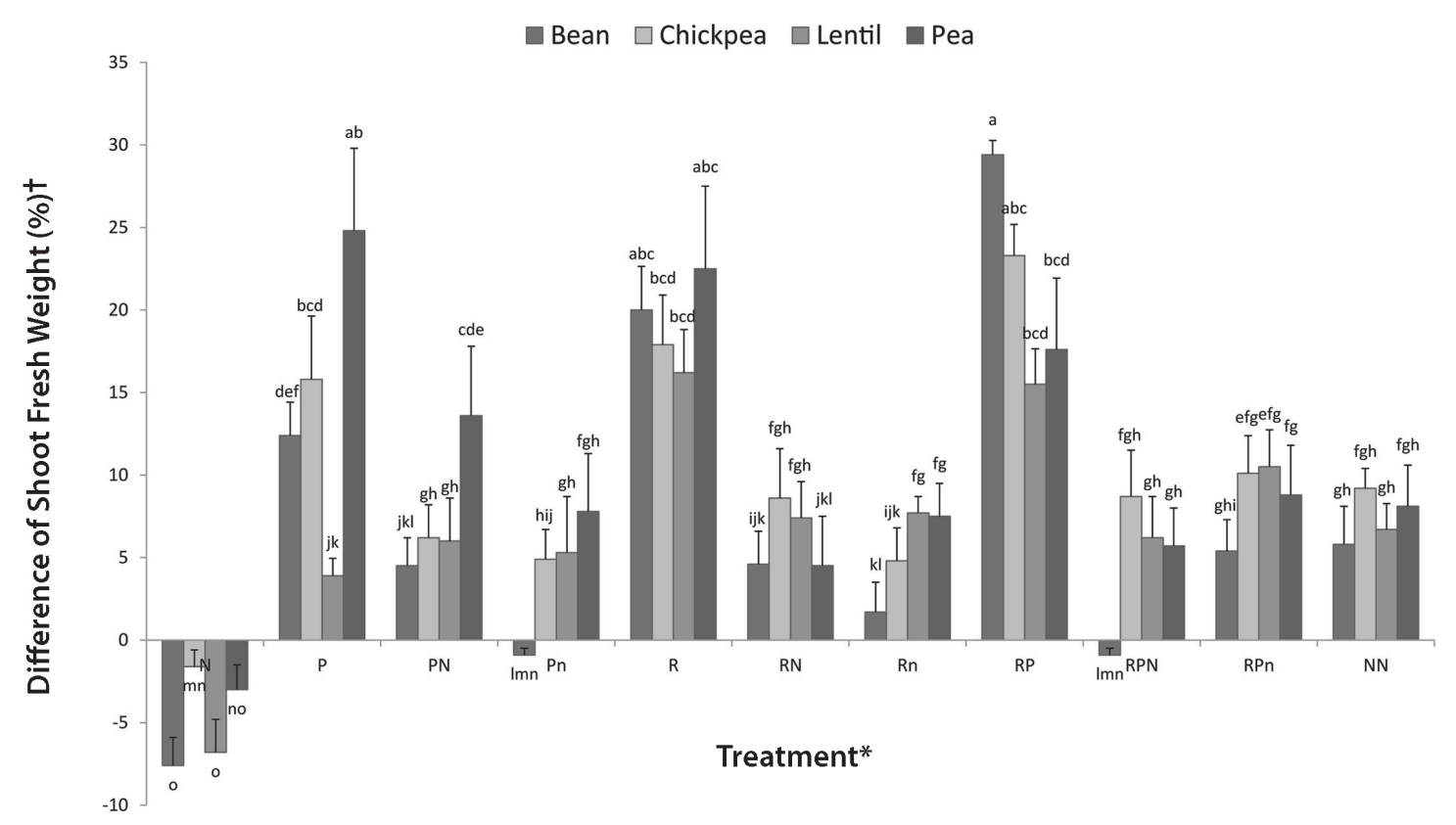

Figure 2. Effect of inoculation with Rhizobium leguminosarum bv. phaseoli and Pseudomonas fluorescens CHAO on shoot fresh weight of legume seedlings infested with root-knot nematode Meloidogyne javanica, as compared with control•

† Each value has been calculated using the equation: $\frac{\text { Treatment mean-control mean }}{\text { control mean }} \times 100$

* Completely randomized design with four replications. Treatment abbreviations are as follows:

$\mathrm{N}$ (nematode), P (pseudomonas), PN (pseudomonas + nematode), Pn (pseudomonas + nematode (a week later)), R (rhizobium), RN (rhizobium + nematode), Rn (rhizobium + nematode (a week later)), RP (rhizobium + pseudomonas), RPN (rhizobium + pseudomonas + nematode), RPn (rhizobium + pseudomonas + nematode (a week later)) and NN (nematode + nematicide).

- Control comprised of healthy untreated seedlings (free of the nematode and bacteria inocula).

Comparisons were carried out using Duncan test $(a=0.05)$; means that do not share the same letter are significantly different $(p \leq 0.05)$.

effect of nematodes on the bacterial nodulation on host roots (Ugwuoke and Eze, 2010). Rhizobia are reported to produce toxic metabolites inhibitory to many plant pathogens (Hmissi et al., 2011). However, in our case, it seems that competition for the host root tissue is the most important concern between the antagonizing organisms (Rhizobium and Meloidogyne).

Pseudomonas can inhibit galling and reproduction of the nematode. These findings coincide with other studies suggesting that $P$. fluorescens $\mathrm{CHAO}$ can be considered as a common biological agent to root-knot nematodes (Saeedizadeh, 2016; Siddiqui et al., 2005).

The combined use of Rhizobium and Pseudomonas was more beneficial in increasing plant growth and reducing nem- atode multiplication, probably due to positive interaction. This positive interaction is evident by the increase in nodulation and the reduction in nematode multiplication. Some strains of $R$. leguminosarum and $P$. flourescens have been used in combination to control root-knot nematodes affecting legumes (Ashoub and Amara, 2010). In our trial, positive cooperative effect of $P$. fluorescens $\mathrm{CHAO}$ and $R$. leguminosarum bv. phaseoli on the plants has been demonstrated by the suppression of activity of $M$. javanica as well as by the host growth enhancement of the legume seedlings. Bayat et al. (2014) showed that the root fresh weight of legumes increased significantly upon rhizobial inoculation. Similar results have been reported in Vicia faba (Dashadi et al., 2011). In faba bean, individual inoculation and co-in- 
oculation of Rhizobium and Azotobacter increased most of growth indicators such as root dry weight. Co-inoculation of Rhizobium and Azotobacter could improve some of the faba bean growth properties under water stress conditions (Dashadi et al., 2011).

Several management strategies have been developed for Meloidogyne spp., nevertheless their usage in subsistence agriculture is restricted. Chemical compounds used to control nematodes are too expensive, and non-chemical practices, such as crop rotation, are limited because of the wide host range of the root-knot nematodes. Biological control agents, such as Pseudomonas and Rhizobium, can allow significant a reduction in the use of nematicides and chemical fertilizers through their numerous direct or indirect mechanisms of action.

In conclusion, according to our results, using a co-inoculum of $P$. fluorescens $\mathrm{CHAO}$ and $R$. leguminosarum bv. phaseoli can be more effective against $M$. javanica, compared with stand-alone application of either bacterium, and will reduce the level of its pathogenic activity. Biological control of the nematode using the bacteria in a joint application cannot be as effective as the commercial synthetic pesticides in the greenhouse. However, the prolonged use of biocontrol agents will reduce the nematode population in long-term, minimizing the risk for development of nematicide resistance, adverse effects to the environment and humans, which are associated with the chemical control. Moreover, bacterial nodulation induced on the legumes root inoculated with $R$. leguminosarum can improve plant growth besides the contribution to biological control of the nematode on the legume roots.

The authors wish to acknowledge and appreciate the Center of Agricultural Research in Pishva, and Shahed University for the financial support of the research.

\section{Literature cited}

Ahemad, M. and Kibret, M. 2014. Mechanisms and applications of plant growth promoting rhizobacteria: Current perspective. Journal of King Saud University-Science, 26: 1-20.

Alizadeh, K., Ghaffari, A. and Kumar, S. 2013. Development of Feed Legumes as Suitable Crops for the Drylands of Iran. ICARDA (International Center for Agricultural Research in the Dry Areas) P.O. Box 114/5055, Beirut, Lebanon.

Ashoub, A.H. and Amara, M.T. 2010. Biocontrol activity of some bacterial genera against root-knot nematode, Meloidogyne incognita. Journal of American Science, 6(10): 321-328.

Aydinli, G. and Mennan, S. 2016. Identification of root-knot nematodes (Meloidogyne spp.) from greenhouses in the Middle Black Sea Region of Turkey. Turkish Journal of Zoology, 40: 1-12.

Bai, Y., Zhou, X. and Smith, D.L. 2003. Crop ecology, management and quality: enhanced soybean plant growth resulting from coinoculation of Bacillus strains with Bradyrhizobium japonicum. Crop Science, 43(5): 1774-1781.

Bayat, L., Askari, M., Amini, F. and Zahedi, M. 2014. Effects of Rhizobium inoculation on Trifolium resupinatum antioxidant system under sulfur dioxide pollution. Biological Journal of Microorganism, 2(8): 37-50.

Beneduzi, A., Ambrosini, A. and Passaglia, L.M.P. 2012. Plant growth-promoting rhizobacteria (PGPR): Their potential as antagonists and biocontrol agents. Genetics and Molecular Biology, 35(4) (Suppl.): 1044-1051.

Bojňanská, T., Frančáková, H., Lišková, M. and Tokár, M. 2012. Legumes-The alternative raw materials for bread production. Journal of Microbiology, Biotechnology and Food Sciences, 1: 876-86.

Dashadi, M., Khosravi, H., Moezzi, A., Nadian, H., Heiari, M. and Radjabi, M. 2011. Co-inoculation of Rhizobium and Azotobacter on growth indices of faba bean under water stress in the green house condition. Advance Studies in Biology, 3(8): 373-85.

Gharabadiyan, F., Jamali, S. and Komeili, H.R. 2013. Determining of root-knot nematode (Meloidogyne javanica) damage function for tomato cultivars. Journal of Agricultural Sciences, 58(2): 147-157.

Gupta, G., Parihar, S.S., Ahirwar, N.K., Snehi, S.K. and Singh, V. 2015. Plant Growth Promoting Rhizobacteria (PGPR): Current and Future Prospects for Development of Sustainable Agriculture. Journal of Microbial \& Biochemical Technology, 7: 96-102.

Hmissi, I., Mabrouk, Y., Abdi, N., Bouraoui, M., Saidi, M. and Sifi, B. 2011. Effects of some Rhizobium strains on chickpea growth and biological control of Rhizoctonia solani. African Journal of Microbiology Research, 5(24): 4080-4090. 
Hosseini Nejad, S.A. and Khan, M.W. 2001. Interaction of root-knot nematode, Meloidogyne incognita (race 1), on chickpea cultivars. Applied Entomology and Phytopathology, 68: 1-11.

Hussey, R.S. and Janssen, G.J.W. 2002. Root-Knot Nematodes: Meloidogyne species. Pp: 43-70. In: J.L. Starr, J. Bridge and R. Cook, (Eds.). Plant resistance to parasitic nematodes. CAB1 Publishing, Walling ford, UK.

Hussey, R.S. and Barker, K.R. 1973. A comparison of methods of collecting inocula of Meloidogyne spp. including a new technique. Plant Disease Reports, 57: 1025-1028.

Jang, J.Y., Choi, Y.H., Shin, TS., Kim, T.H., Shin, K.S., Park, H.W., Kim, Y.H., Kim, H., Choi, G.J., Jang, K.S., Cha, B., Kim, I.S., Myung, E.J. and Kim, J.C. 2016. Biological Control of Meloidogyne incognita by Aspergillus niger F22 Producing Oxalic Acid. PLOS ONE, 11(6): 1-15.

Jenkins, W.R. 1964. A rapid centrifugal flotation technique for separating nematodes from soil. Plant Disease Report, 48:692.

Lipiec, J. and Glinski, J. 2011. Rhizosphere. In Encyclopedia of Agrophysics; Gli nski, J., Horabik, J., Lipiec, J., Eds.; Springer: Dordrecht, The Netherlands, pp.705-709.

Muthulakshmi, M., Devrajan, K. and Jonathan, E.I. 2010. Biocontrol of root knot nematode, Meloidogyne incognita (Kofoid and White) Chitwood in mulberry (Morus alba L.). Journal of Biopesticides, 3(2): 479-482.

Nicol, J.M. 2002. Important nematode pests. In: Curtis BC, Rajaram S, Gómez M (Eds.) Bread wheat improvement and production. FAO Plant Production and Protection Series 2002, p 567.

Nihorimbere, V., Ongena, M., Smargiassi, M. and Thonart, P. 2011. Beneficial effect of the rhizosphere microbial community for plant growth and health. Biotechnology, Agronomy, Society and Environment, 15(2): 327-337.

Ntalli, N.G., Caboni, P. 2012. Botanical nematicides: a review. Journal of Agricultural and Food Chemistry, 60(40): 9929-40.

Onyeke, C.C. and Akueshi, C.O. 2012. Pathogenicity and reproduction of Meloidogyne incognita (Kofoid and White) Chitwood on African yam bean, Sphenostylis stenocarpa (Hochst Ex. A. Rich) Harms accessions. African Journal of Biotechnology, 11(7): 1607-1616.

Osei, K., Gowen, S.R., Pembroke, B., Brandenburg, R.L. and Jordan, D.L. 2010. Potential of Leguminous Cover Crops in Management of a Mixed Population of Root-knot Nematodes (Meloidogyne spp.). Journal of Nematology, 42(3): 173-178.

Panizzon, J.P., Júnior, H.L.P., Knaak, N., Ziegler, D.R., Ramos, R.C. and Fiuza, L.M. 2016. Bacteria-SoilPlant Interaction: This Relationship to Generate can Inputs and New Products for the Food Industry. Journal of Rice Research, 4(165): 1-6.
Perry, R.N. and Moens, M. 2006. Plant Nematology. Printed and bound in the UK by Biddles Ltd, King's Lynn. 447p.

Sadovinkova, Y.N., Bespalova, L.A. and Antonyuk, L.P. 2003. Wheat gram agglutinin is a grown factor for bacterium Azospirillum brasilense. Doklady Biochemistry and Biophysics, 398(1-6): 103-105.

Saeedizadeh, A. 2016. Trichoderma viride and Pseudomonas fluorescens CHAO against Meloidogyne javanica in the rhizosphere of tomato plants. Hellenic Plant Protection Journal, 9: 28-34.

Safdar, H., Javed, N., Khan, S.A., Haq, I., Safdar, A. and Khan, N.A. 2012. Control of Meloidogyne incognita (Kofoid and White) Chitwood by Cadusafos (Rugby ${ }^{\circ}$ ) on Tomato. Pakistan Journal of Zoology, 44(6): 1703-1710.

Shaikh, S.S., Sayyed, R.Z. and Reddy, M.S. 2016. Plant Growth Promoting Rhizobacteria: A Sustainable Approach to Agro-ecosytstem. In book: Plant, Soil and Microbes-Interactions and Implications in Crop Science., Edition: 1, Publisher: Springer international publishing AG, Switzerland. Editors: K R Hakeem et al, pp. 181-201.

Siddiqui, Z.A. and Akhtar, M.S. 2009. Effect of plant growth promoting rhizobacteria, nematode parasitic fungi and root-nodule bacterium on root-knot nematodes Meloidogyne javanica and growth of chickpea. Biocontrol Science and Technology, 19(5): 511-521.

Siddiqui, Z.A., Fatima, M. and Alam, S. 2013. Interactions of Meloidogyne incognita, Xanthomonas campestris, and Rhizobium sp. in the disease complex of chickpea. Turkish Journal of Agriculture and Forestry, 37: 173-178.

Siddiqui, I.A., Haas, D. and Heeb, S. 2005. Extracellular Protease of Pseudomonas fluorescens CHAO, a Biocontrol Factor with Activity against the Root-Knot Nematode Meloidogyne incognita. Applied and Environmental Microbiology, 71(9): 5646-5649.

Siddiqui, I.A., Shaukat, S.S., Sheikh, I.H. and Khan, A. 2006. Role of cyanide production by Pseudomonas fluorescens CHAO in the suppression of root-knot nematode, Meloidogyne javanica in tomato. World Journal of Microbiology and Biotechnology, 22: 641-650.

Sokhandani, Z., Moosavi, M.R. and Basirnia, T. 2016. Optimum Concentrations of Trichoderma longibrachiatum and Cadusafos for Controlling Meloidogyne javanica on Zucchini Plants. Journal of Nematology, 48(1): 54-63.

Tian, B., Yang, J. and Zhang, K. 2007. Bacteria used in the biological control of plant parasitic nematodes: populations, mechanisms of action, and future prospects. FEMS Microbiology and Ecology, 61: 197-213.

Ugwuoke, K.I. and Eze, S.C. 2010. The effect of mycorrhiza (Glomus geosporum), Rhizobium and Meloidogyne incognita on growth and develop- 
ment of cowpea (Vigna unguiculata L. Walp). Research Journal of Agriculture and Biological Sciences, 6(6): 937-941.

Wang, Y.X. and Oyaizu, H. 2009. Evaluation of the phytoremediation potential of four plant species for dibenzofu-ran-contaminated soil. Journal of Hazardous Materials, 168: 760-764.
Weller, D.M. and Cook, R.J. 1983. Suppression of Take-all of Wheat by Seed Treatments with Fluorescent Pseudomonads. Phytopathology, 78: 463-469.

Received: 24 October 2016; Accepted: 14 January 2017

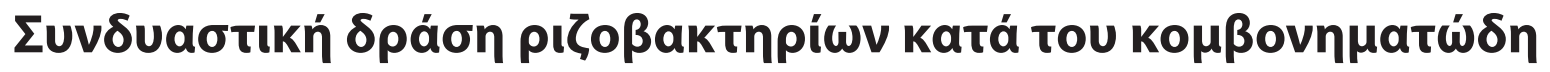

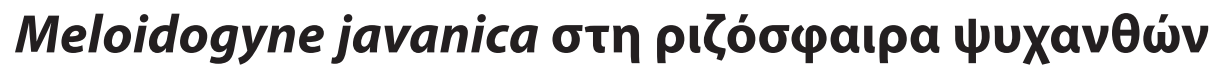

\section{F.-S. Tabatabaei kaı A. Saeedizadeh}

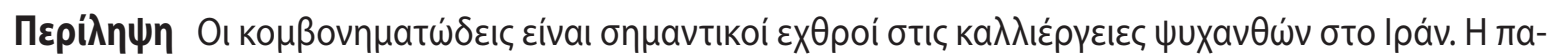

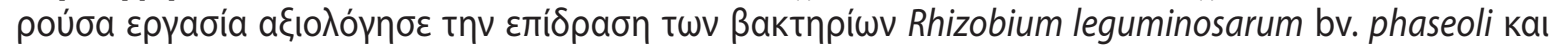

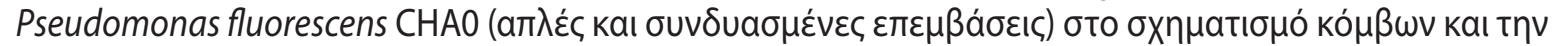

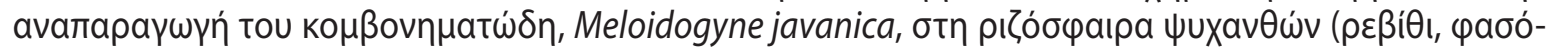

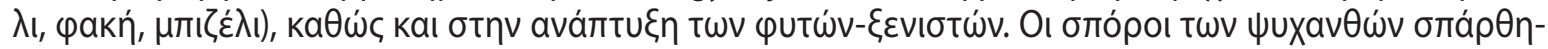

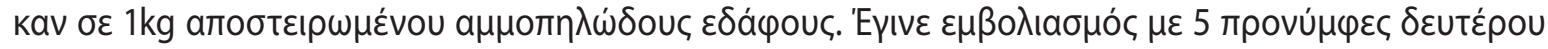

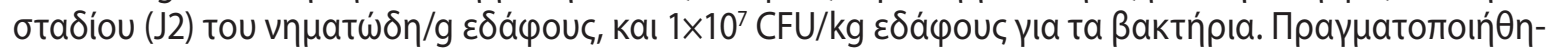

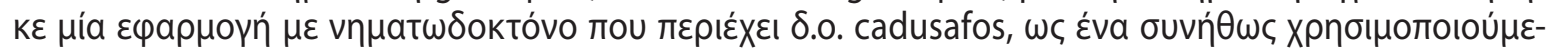

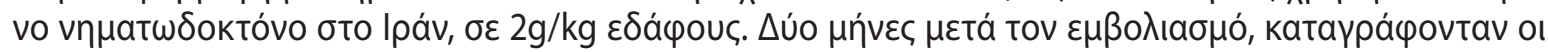

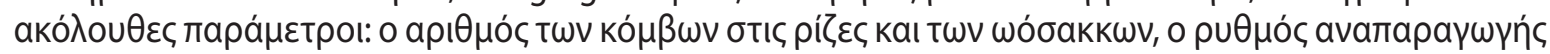

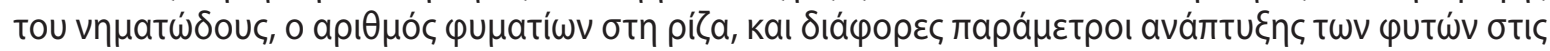

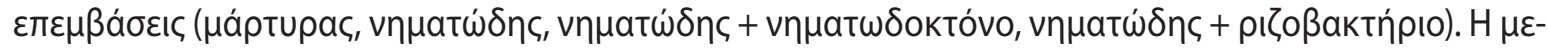

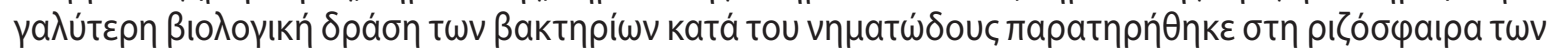

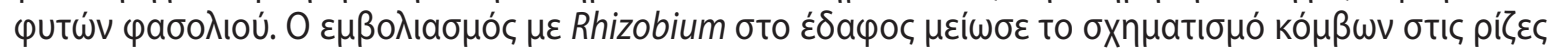

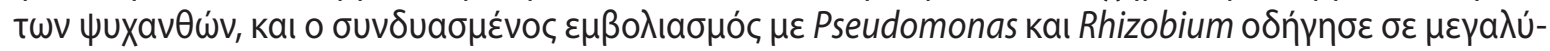

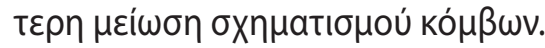

